\title{
Homologies between T Cell Receptor Junctional Sequences Unique to Multiple Sclerosis and T Cells Mediating Experimental Allergic Encephalomyelitis
}

\author{
Mark Allegretta, * Richard J. Albertini, ${ }^{\star}$ Mark D. Howell, $\$$ Lawrence R. Smith, ${ }^{\S}$ Roland Martin," Henry F. McFarland," \\ Subramamiam Sriram, ' Steven Brostoff, ${ }^{\mathbf{5}}$ and Lawrence Steinman* \\ * Department of Neurology and Neurological Sciences, Beckman Center, Stanford University School of Medicine, Stanford, California \\ 94305-5429; ${ }^{\ddagger}$ Genetics Laboratory and ${ }^{1}$ Department of Neurology, University of Vermont, Burlington, Vermont 05401; ${ }^{\circledR}$ The Immune \\ Response Corporation, Carlsbad, California 92008; and the "Neuroimmunology Branch, National Institute of Neurological Disorders \\ and Stroke, National Institutes of Health, Bethesda, Maryland 20892
}

\begin{abstract}
The selection of $\mathbf{T}$ cell clones with mutations in the hypoxanthine guanine phosphoribosyltransferase (hprt) gene has been used to isolate $T$ cells reactive to myelin basic protein (MBP) in patients with multiple sclerosis (MS). These $T$ cell clones are activated in vivo, and are not found in healthy individuals. The third complementarity determining regions (CDR3) of the $T$ cell receptor (TCR) $\alpha$ and $\beta$ chains are the putative contact sites for peptide fragments of MBP bound in the groove of the HLA molecule. The TCR V gene usage and CDR3s of these MBP-reactive hprt $^{-} \mathrm{T}$ cell clones are homologous to TCRs from other $T$ cells relevant to MS, including $\mathbf{T}$ cells causing experimental allergic encephalomyelitis (EAE) and T cells found in brain lesions and in the cerebrospinal fluid (CSF) of MS patients. In vivo activated MBP-reactive $T$ cells in MS patients may be critical in the pathogenesis of MS. (J. Clin. Invest. 1994. 94:105-109.) Key words: hypoxanthine phosphoribosyltransferase • in vivo • mutation • T lymphocytes - myelin basic protein.
\end{abstract}

\section{Introduction}

In experimental allergic encephalomyelitis (EAE) ${ }^{1}$ discrete epitopes of myelin basic protein (MBP) have been identified, and disease can be induced by immunization with these peptides

Address correspondence to Mark Allegretta, Ph.D., Department of Neurology, Beckman Center Room B002, Stanford University Medical Center, Stanford, CA 94305-5429.

M. D. Howell's current address is Department of Microbiology, Colorado State University, Fort Collins, CO 80523.

R. Martin's current address is Department of Neurology, HoppeSeyler St. 3, W-7400, Tubingen, Germany.

S. Sriram's current address is Department of Neurology, Medical Center South, Vanderbilt University, Nashville, TN 37212.

S. Brostoff is affiliated with the Medical University of South Carolina, Charleston, SC and the University of California, San Diego and Irvine, CA.

Received for publication 21 October 1993 and in revised form 10 February 1994.

1. Abbreviations used in this paper: CDR3, third complementarity determining region; CSF, cerebrospinal fluid; EAE, experimental allergic encephalomyelitis; hprt, hypoxanthine guanine phosphoribosyl-transferase gene; MBP, myelin basic protein; Mf, mutant frequency; MS, multiple sclerosis.

The Journal of Clinical Investigation, Inc.

Volume 94, July 1994, 105-109 of MBP (1) or by transfer of T cell clones reactive to these peptides (2). Despite the recognition of different encephalitogenic epitopes of MBP in the context of different major histocompatability complex (MHC) backgrounds in different species or strains of animals, encephalitogenic clones show a preference for use of certain TCR V $\alpha$ and $\beta$ s (3-5). In B10.PL mice, $\mathrm{V} \beta$ 8.2 and $\mathrm{V} \alpha 2.3$ are used by encephalitogenic clones which recognize the $\mathrm{NH}_{2}$-terminal peptide residue 1-9 of MBP presented by I-A ${ }^{u}$. In Lewis rats, the recognition of MBP 68-88 in the context of I-A by encephalitogenic clones is carried out by $\mathrm{T}$ cell receptors (TCRs) homologous to $\mathrm{V} \beta 8.2$ and $\mathrm{V} \alpha 2$. Restriction in TCR usage in pathogenic clones provided a rationale for therapies that prevent and reverse EAE with MHC class II-specific, or $\mathrm{V} \beta$ specific monoclonal antibodies (6-8). The third complementarity determining region (CDR3) of TCR $\beta$ chains expressed by these clones also show similarities, with conserved deduced amino acid motifs of DSGNTE, DSSNTE, or related sequences repeatedly observed in the rat clones responsive to MBP $68-88$. To this end, TCR-directed peptide vaccines have been used successfully to prevent $\operatorname{EAE}(9,10)$. Because various selective regimens of immunotherapy aimed at MBP responsive T cells have shown great promise in EAE, efforts have been made to identify equivalent $T$ cell clones in humans with MS.

The study of MBP-reactive $\mathrm{T}$ cells in humans has been enigmatic because MBP-reactive $T$ cells can be detected in multiple sclerosis (MS) patients as well as in normal individuals. Studies exist which either support $(11,12)$ or refute $(13-$ 15 ) the concept of restricted TCR expression by MBP-reactive human $\mathrm{T}$ cell clones. In one study, $\mathrm{V} \beta 17$ and 12 were used by $T$ cell clones reactive with the 84-102 epitope of human MBP by individuals with the MHC haplotype DR2, an HLA class II phenotype conferring susceptibility to MS. Interestingly, $\mathrm{V} \beta 12$ in man is most homologous to mouse and rat $\mathrm{V} \beta$ 8.2. Kotzin and colleagues find a remarkable bias for $\mathrm{V} \beta 5.2$ and 6.1 in MBP-specific T cell clones from HLA-DR2 MS patients. Studies on the TCR expression within tissue compartments involved in MS show that in plaques from 16 MS brains taken at autopsy, expression of TCR V $\beta 5.2$ and 6 genes was evident in demyelinated plaques from patients that were HLA-DR2Dw2 and DNA typed as DRB $1 * 1501$, DQA $1 * 0102$, DQB $1 * 0602$, DPB $1 * 0401$ $(16,17)$. Similarly, $\mathrm{T}$ cells expressing $\mathrm{V} \beta 12$ have been observed in oligoclonally expanded $\mathrm{T}$ lymphocytes from CSF of patients with MS (18) and in some MS brain plaques (19), suggesting selective recruitment to the MS brain of $\mathrm{T}$ cells expressing this gene. These studies suggest that a limited array of TCRs are expressed by potentially pathogenic $\mathrm{T}$ cells from the CSF and plaques of MS patients.

The hprt gene is on the $\mathrm{X}$ chromosome at Xq26-27.2, spans 
$44 \mathrm{~kb}$ and contains nine exons (20). The location of $h p r t$ results in true or functional hemizygosity in all nucleated human cells, facilitating the development of a cloning assay for $\mathrm{T}$ cells deficient in this enzyme $(21,22)$. The range of mean values of spontaneous mutant frequencies (Mfs) in normal adults is 3.1$9.5 \times 10^{-6}$ and a mean value ( \pm standard deviation) for 252 individuals is $5.3( \pm 2.7) \times 10^{-6}(23)$. If spontaneous hprt mutations arise preferentially in dividing rather than quiescent $\mathrm{T}$ cells in vivo, then selection for $\mathrm{T}$ cells with mutations in the hprt gene will enrich for cells that have undergone in vivo division. We have used this assay to isolate a class of MBPreactive $T$ cell clones from MS patients that may represent $T$ cells activated in vivo to MBP (24), and have shown that MBPreactive $T$ cells are present within this population of activated cells in MS patients, yet such reactive clones are absent from the mutant fraction of $T$ cells from normal individuals. Although similar frequencies of MBP-reactive $T$ cells can be detected in vitro in both MS patients and normal individuals, they are unlikely to be dividing in vivo in normals, and hence are unlikely to acquire mutations in the hprt gene and will be absent in this population of $\mathrm{T}$ cells from normal controls. In an initial survey of $258 \mathrm{hprt}^{-} \mathrm{T}$ cell clones from six MS patients, 11 proliferated in response to human MBP without prior in vitro exposure to this antigen. None of 93 wild-type clones from MS patients and none of $113 \mathrm{hprt}^{-}$or 32 wild type clones isolated from three normal individuals responded to MBP when tested in the same manner. MBP-reactive $\mathrm{T}$ cell clones were isolated from one female and four male patients; the three controls were males. Although hprt is on the $\mathrm{X}$ chromosome, there is no apparent bias in Mf between males and females, presumably due to irreversible random $\mathrm{X}$ inactivation. Likewise, there is no bias in selection for MBP reactivity in these clones, since all clones are initially propagated nonspecifically in the absence of MBP. All patients tested for reactivity had chronic progressive MS, and hprt Mfs ranged from 8.0 to $81.3 \times 10^{-6}$. Of 11 clones initially reported, six clones from two MS patients were available for molecular analysis of the TCR. The TCR $\beta$ of one clone (M13) was unobtainable with the PCR methods used in this study.

\section{Methods}

$T$ cell cloning. Patient information and methods used for the generation of these clones has been described (24).

PCR amplification of TCRs. cDNA was subjected to enzymatic amplification by the PCR method. $10 \mu \mathrm{l}$ cDNA was combined in a $50-\mu \mathrm{l}$ reaction mix with $4 \mu \mathrm{l} 10 \times$ PCR buffer, 1.25 U Taq polymerase (Perkin-Elmer Corp., Norwalk, CT), 0.5 $\mu \mathrm{M}$ of $\mathrm{C} \alpha$ or $\mathrm{C} \beta$ primer, and $0.5 \mu \mathrm{M}$ of $\mathrm{V} \alpha$ or $\mathrm{V} \beta$ specific oligonucleotide primer. Primers were synthesized by Operon Technologies (Alameda, CA). The PCR profile used was: denaturation $95^{\circ} \mathrm{C}$ for $60 \mathrm{~s}$, annealing $55^{\circ} \mathrm{C}$ for $60 \mathrm{~s}$ and extension $72^{\circ} \mathrm{C}$ for $60 \mathrm{~s}$ for 35 cycles in a DNA Thermal Cycler (PerkinElmer Corp.). The size of amplified products using $5^{\prime}-\mathrm{V} \alpha$ sense and $3^{\prime}-\mathrm{C} \alpha$ antisense primers ranged from $\sim 300$ to $420 \mathrm{bp}$. The size of amplified products using $5^{\prime}-\mathrm{V} \beta$ and $3^{\prime}-\mathrm{C} \beta$ primers ranged from $\sim 180$ to $400 \mathrm{bp}$. Primers used in this study have been previously described (16).

Direct sequencing of PCR-amplified DNA. After PCR and identification of appropriate $\mathrm{V} \alpha$ or $\beta$, the TCR is re-amplified as follows: $10 \times$ buffer, $8 \mu \mathrm{l} ; 2.5 \mathrm{mM}$ dNTPs, $8 \mu \mathrm{l}$; PCR product, $1 \mu \mathrm{l}$; C region primer $(50 \mu \mathrm{M}), 1 \mu \mathrm{l}$; V region primer $(50$ $\mu \mathrm{M}), 1 \mu \mathrm{l}$; sterile $\mathrm{H}_{2} \mathrm{O}, 80.5 \mu \mathrm{l}$; Taq polymerase, $0.5 \mu \mathrm{l}$; amplify by 30 cycles. The PCR product is run on a $2 \%$ NuSieve gel in TAE buffer, the appropriate band is excised and isolated with GeneClean. $50 \mathrm{ng}$ of DNA is adjusted to a volume of $8 \mu \mathrm{l}$ and $2 \mu \mathrm{l}$ of $2 \mathrm{~N} \mathrm{NaOH}$ is added. The sample is then incubated at room temperature for $5 \mathrm{~min}$. $1 \mu \mathrm{l}$ of sequencing primer (after dilution to $5 \mu \mathrm{M}$ ) is added as is $6 \mu \mathrm{l} \mathrm{H}_{2} \mathrm{O}$. The sample is then

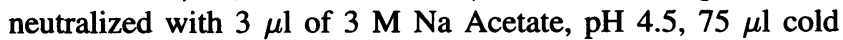
alcohol is added and the sample is then incubated in a $-70^{\circ} \mathrm{C}$ isopropanol bath for $20 \mathrm{~min}$. After centrifugation for $20 \mathrm{~min}$ at $4^{\circ} \mathrm{C}$, the pellet is washed once with $70 \%$ alcohol, centrifuged for $20 \mathrm{~min}$ and dried. The sample is then reconstituted with 8 $\mu \mathrm{l}$ water and sequenced with Sequenase ${ }^{\mathrm{TM}}$ according to manufacturer's instructions. PCR contamination of these clones by rodent DNA can be ruled out by the fact that both the $\mathrm{C}$ region and $\mathrm{V}$ regions sequenced with these CDR3s are identical to published human TCR sequences. PCR products from some of these clones were also sequenced with a second $C$ region primer $5^{\prime}$ to both the primer used for initial amplification and the primer used for initial sequencing. Throughout the paper we use the TCR residue numbering as found in Chothia et al. (25), using positions 90 and 92 as the conserved cysteine $V$ region residue, and positions 107 and 109 as the conserved glycine $\mathrm{J}$ region residue for TCR $\alpha$ and $\beta$, respectively, to delineate the CDR3.

\section{Results}

Of the five $\mathrm{hprt}^{-}$clones tested, two clones (M12 and M26) expressed $\mathrm{V} \alpha$ 8.2, two expressed $\mathrm{V} \alpha 2$ (M13 and M18) and one $\mathrm{V} \alpha 4$ (M27). J $\alpha$ expression was heterogeneous, with expression of $\mathrm{J} \alpha \mathrm{A}, \mathrm{H}, \mathrm{I}$, and $\mathrm{U}$ genes detected. Although no similarities in the usage of $\mathrm{J}$ genes was observed, the deduced amino acid sequence of the TCR $\alpha$ chain CDR3 of clone M12 was identical to the CDR3 of the encephalitogenic SJLxPL/J F1 T cell clone, named F1-12 which is specific for MBP 1-11 (5). The four amino acids "ERNT" are encoded by the $\mathrm{N}$ and $J$ regions of this clone, and the identical sequence is seen in clone $\mathrm{M} 12$, also encoded by $\mathrm{N}$ and $\mathrm{J}$ region nucleotides (Fig. 1). The $\mathrm{V} \alpha$ and $\mathrm{J} \alpha$ usage and $\mathrm{V}-\mathrm{J}$ nucleotide and deduced amino acid sequences for each of these clones is shown in Fig. 1. Thus, an hprt mutant clone found only in MS patients has an identical CDR3 sequence with a pathogenic $T$ cell clone identified in mice that causes paralysis and EAE.

Of the five hprt $^{-}$clones sequenced, four expressed $\mathrm{V} \beta 12$ and one expressed $\mathrm{V} \beta$ 5.1. Clones M12, M18 and M27, all from patient 3, and M17 from patient 1 , expressed $V \beta 12$, and clone M26, also from patient 3, used $\mathrm{V} \beta$ 5.1. The observation that these clones express TCRs of either $\mathrm{V} \beta 12$ or $\mathrm{V} \beta 5$ families, two $\mathrm{V} \beta$ s reported to be expressed extensively by MBP-reactive clones, is intriguing. DR typing by PCR of patient 3 showed a DR $\beta 1 * 0301,1501$; DQ $\alpha 1 * 0102,0501 ; \mathrm{DQ} \beta 1 * 0201,0602$; $\mathrm{DP} \beta 1 * 0201,0202$ molecular phenotype. $\mathrm{V} \beta 5.2$ was reported to be expressed by MBP-reactive clones from DR2 individuals (12). The DRB $1 * 1501$, DQB $1 * 0602$ molecular phenotype has been shown to correlate with expression of $\mathrm{V} \beta 5.1,5.2$, or 6 in MS plaques (17).

Clone M27 transcribes TCR V $\beta 12$ and rearranges a CDR3 region encoding the deduced amino acid sequence "ETSGNT." This six-amino acid region bears similarity to the consensus motif in the CDR3 region of encephalitogenic Lewis rat clones $(3,4)$. The first two amino acids represent conservative charge 


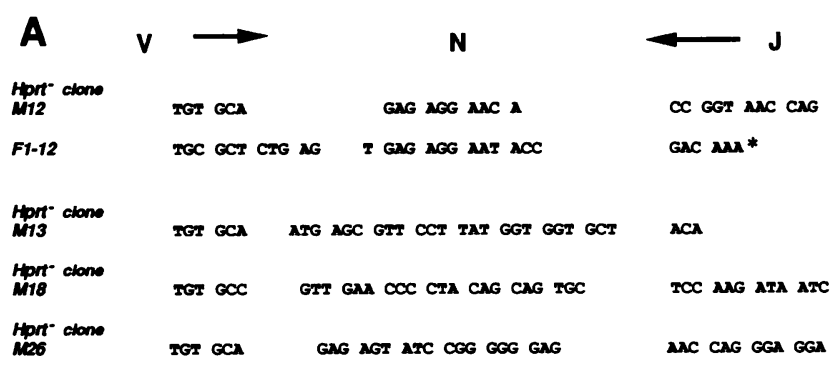

\begin{tabular}{|c|c|c|c|c|c|}
\hline Clone & $v \alpha$ & \multicolumn{3}{|c|}{ CDR3 } & $d \alpha$ \\
\hline لـلسسبسلبل & شلبس & 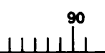 & & & \\
\hline Hort clone M 12 & 82 & SAVYFCA & ERerT & GNQFY & $\boldsymbol{u}$ \\
\hline F1-12 & Va PJA-25 & $\mathrm{CA}$ & LSERWT & DK & Ja F1-12* \\
\hline Hort clone $\mathrm{N}_{13}$ & 2 & SATYLCA & MSVPYGGA & TNKLIFGT & I \\
\hline Hprr clone W 18 & 2 & SATYLCA & VEP LQQC & SKII & A \\
\hline Horr clone W 26 & 82 & SAVYFCA & ESIRGE & NQGGK & $H$ \\
\hline Hort clone M 27 & 41 & & & & \\
\hline
\end{tabular}

Figure 1. TCR $\alpha$ chain usage and J region nucleotide $(A)$ and deduced amino acid sequences $(B)$ of $h_{p r t}^{-}$MBP-reactive T cell clones from MS patients. $\mathrm{V} \alpha$ and $\mathrm{J} \alpha$ genes used are shown for each clone designated. $\mathrm{J} \alpha$ sequences were derived by direct sequencing of PCR products after 35 cycles of amplification with specific $\mathrm{V}$ region primers. Germline sequences of $\mathrm{V} \alpha$ and $\mathrm{J} \alpha$ are from Klein et al. (32). (*) Acha et al. (5).

substitutions of $\mathrm{D}$ and $\mathrm{S}$, two amino acids consistently found at the beginning of CDR3s of many encephalitogenic Lewis rat clones. The likelihood that these VDJ sequences occurred in this $\mathrm{V} \beta$ 12-expressing clone by chance is low, as no such sequences were detected in sequencing of five control $\mathrm{hprt}^{+} \mathrm{T}$ cell clones from the same patient. Also, in sequencing the VDJs of interleukin 2-receptor ${ }^{+} \mathrm{T}$ cells from the synovium of patients with rheumatoid arthritis, this motif was not detected in over 30 clones sequenced (26). To determine if the CDR3 sequences of these clones were similar to other TCRs of relevance to MS, sequencing of $\mathrm{V} \beta 12$ TCRs derived from lymphocytes without culture from the CSF of an MS patient was performed. T cells from a sample of CSF were amplified with $\mathrm{C} \beta$ and $\mathrm{V} \beta 12$ primers, and the PCR products were then cloned and sequenced. Five of 15 clones analyzed showed a $\mathrm{V} \beta$ 12.2-J $\beta 2.3$ rearrangement, with a CDR3 sequence of "GSNTD." Again, the conservative charge substitution of $D$ for $E$ is seen between this TCR and the conserved rat CDR3, and glutamic acid and serine precede NTE, NTGE, or NTD as they do in the rat CDR3, as well as the CDR3 of clone M27. Thus, in two types, hprt $^{+}$and hprt $^{-}$, of MBP-reactive clones, and in V $\beta 12$ TCRs from T cells in the CSF of MS patients, similar CDR3 $\beta$ s were seen. These human $\mathrm{CDR} 3 \beta$ sequences are homologous to those of pathogenic $\mathrm{T}$ cells capable of causing EAE and paralysis in rodents.

Sequence analysis of $\mathrm{hprt}^{-}$clone M26 showed similarity to another CDR3 relevant to MS. This clone expresses $\mathrm{V} \beta 5.1$ and $\mathrm{J} \beta$ 2.2, with a CDR3 sequence of LGGP. This is a near match to a predominant CDR3 found in $\mathrm{V} \beta 5.2$ TCRs derived from MS brain, where a sequence of LGGVP was seen (17).
Also, Lewis rat clones isolated from the lymph nodes of animals immunized with MBP 85-99 often express a CDR3 of LGGE in conjunction with $\mathrm{V} \beta 6(27)$.

The presence of CDR3 motifs in MBP-reactive T cells has also been observed in certain MS patients in MHC class IIrestricted cytolytic $T$ cell clones specific for MBP-coated EBVtransformed B lymphoblasts (14). One such clone that has been isolated recognizes $\mathrm{COOH}-$ terminal residues of human MBP, which are encephalitogenic in non-human primates (cytolytic $\mathrm{V} \beta 4.2$ clone, Fig. $2, A$ and $B$ ). This clone expresses $\mathrm{V} \beta 4.2$ and $\mathrm{J} \beta 2.1$, and has a CDR3 $\beta$, SGDQG, with homology to the rat and mouse motif. This CDR3 is also strikingly similar to the CDR3 of the MBP-reactive hprt ${ }^{-}$clone M12, which expresses a sequence of GSDQG. Both clones also use $\mathrm{J} \beta$ 2.1. Thus, the only difference between these clones in the CDR3 and J region is the inversion of the GS residues at the start of the CDR3. The $\mathrm{V} \beta$ and $\mathrm{J} \beta$ usage, and the $\operatorname{CDR} 3 \beta$ nucleotide and deduced amino acid sequences of these TCRs are shown in Fig. 2, $A$ and $B$.

To further establish the uniqueness of these TCR sequences to the population of $\mathrm{hprt}^{-} \mathrm{T}$ cells from MS patients, we sequenced the TCR $\beta$ s of six wild-type clones. Fig. 3, $A$ and $B$ shows the $\operatorname{TCR} \beta$ nucleotide and deduced amino acid sequences of wild-type T cell clones W5, W9, W11, W21, W26, and W30. These PHA-activated clones were generated from the patient for which the hprt mutant $\mathrm{T}$ cell clones are described, and were taken at the same time of sampling as the prt $^{-}$clones. The $\mathrm{V}$ regions expressed by these clones are diverse $(\mathrm{V} \beta 3,14,9,18$, 21 , and 8 , respectively), as are the $\mathrm{J}$ regions $(\mathrm{J} \beta 2.7,2.5,2.1$, $1.1,1.1$, and 2.1 , respectively). Moreover, the deduced amino acid sequences of the CDR3s show no homology to any of the hprt $^{-}$clones, encephalitogenic T cell clones from rodents, TCR $\mathrm{V} \beta 12$ sequences from the CSF, or TCRs found within the MS lesion as reported here. These results support our observations of CDR3 sequence homologies being unique to this population of $\mathrm{T}$ cells from MS patients.

\section{Discussion}

It is interesting that MBP-reactive prt $^{-} \mathrm{T}$ cell clones from MS patients use $\mathrm{V} \beta$ s with a high degree of homology to encephalitogenic MBP-reactive $T$ cell clones from the mouse and rat. One interpretation may be that unique combinations of particular $\mathrm{V}$ regions, in addition to precise amino acid sequences in the CDR3s, may contribute to the autoreactive nature of such $T$ cells (28). The observation of $\mathrm{T}$ cells rearranging $\mathrm{V} \beta 12$ in the CSF (18) and brain (19) of MS patients is consistent with the hypothesis of sequestration of reactive $\mathrm{T}$ cells at the site of inflammation proposed to occur for rheumatoid arthritis (26, 29). Absence of $\mathrm{V} \beta$ 12-bearing $\mathrm{T}$ cells in the periphery with a high degree of clonal expansion of $\mathrm{V} \beta 12^{+} \mathrm{T}$ cells in the CSF of MS patients would support this notion. Studies on the frequency of $\mathrm{V} \beta 12$ expression in $\mathrm{T}$ cells from the CD4 and CD8 compartments of peripheral blood lymphocytes taken from MS patients, show no differences compared to healthy controls (data not shown), though the frequency of such cells is $<3 \%$ in all 12 MS patients analyzed.

The most striking example of CDR3 sharing is seen between the encephalitogenic clone F1-12 and the hprt $^{-}$M12, with identical CDR3 $\alpha$ sequences of "ERNT.', Clone F1-12 responds to the acetylated $\mathrm{NH}_{2}$-terminal residues $1-11$. The clones described in this study all react to the $113-142$ peptide of MBP. 
A

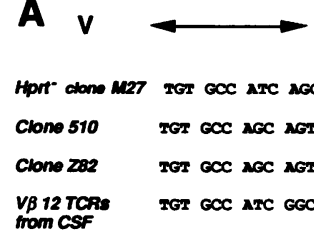

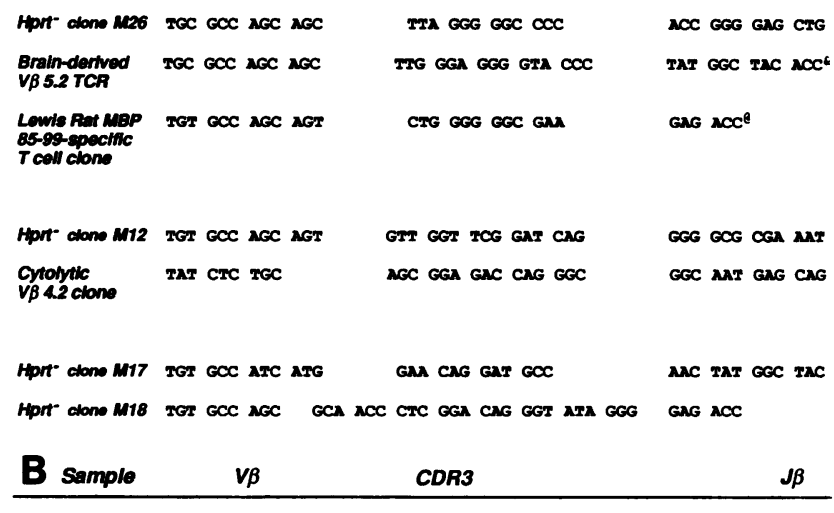

\begin{tabular}{|c|c|c|c|c|c|}
\hline Hprr clono M 27 & 12 & CAIR & ETSG & NTGILFFGEG & 2.2 \\
\hline $\begin{array}{l}\text { Encephallitogonic } \\
\text { Lewis ret clono } 510\end{array}$ & 8.2 & CASS & DSS & NTEVFFGKGTRLT & $1.2 *$ \\
\hline $\begin{array}{l}\text { Encophalitogonic } \\
\text { Lewis rat clono Z82 }\end{array}$ & 8.2 & CASS & DSG & NTEVVFFGKGTRLT & $1.2 \ddagger$ \\
\hline CSF-derived TCRs & 12.2 & FCAI & GS & NTDTQYFGPGTRLT & 2.3 \\
\hline
\end{tabular}

$\begin{array}{llllll} & 12.2 & \text { FCAI } & \text { GS } & \text { NTDTQYFFGPGTRT } & 2.3\end{array}$

\begin{tabular}{|c|c|c|c|c|}
\hline tprer clone M 26 & 5.1 & CASS & LGGP & TGELFFGEG \\
\hline $\begin{array}{l}\text { US-brain-dertuod } \\
\text { UA 5.2 sequence }\end{array}$ & 5.2 & CASS & LGGVP & YGYTFGSGTRLT \\
\hline $\begin{array}{l}\text { Lowis rat mBPP 85-99 } \\
\text { spocific clone }\end{array}$ & 8.2 & CASS & LGGI & ETGYFGPGTRLL \\
\hline
\end{tabular}

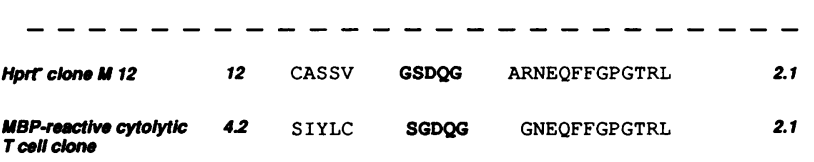

\begin{tabular}{|c|c|c|c|c|}
\hline Hpre clone W 17 & 12 & CAIM & EQDA & NYGYTFGSGTRLT \\
\hline Hpre clone W 18 & 12 & CAS & ATLGQGIG & ETOYFGPGTRLLVLED \\
\hline
\end{tabular}

Figure 2. TCR $\beta$ chain usage and $\mathrm{D}-\mathrm{J}$ region nucleotide $(A)$ and deduced amino acid sequences $(B)$ of $h_{p r t}^{-}$MBP-reactive T cell clones from MS patients. CDNA was subjected to enzymatic amplification by PCR, and direct sequencing of PCR-amplified TCR CDNA is performed as described in Methods. Nucleotide sequence and amino acid residues of encephalitogenic MBP-reactive T cell clones from Lewis rats, as well as brain-derived V $\beta$ 5.2 TCRs, are shown for comparison. Germline $\mathrm{V} \beta$ and $\mathrm{J} \beta$ sequences are from Kimura et al. (33) and Concannon et al. (34). *Ref. 34; ${ }^{\ddagger}$ ref. 4; ${ }^{8}$ ref. 17; ${ }^{11}$ ref. 27.

From studies using alanine-substituted peptides, it has been shown that the minimal residues necessary for inducing EAE and $\mathrm{T}$ cell activation for Ac 1-11-reactive clones is the conservation of residues 3-6 which is a sequence of "QKRP" (30), and peptides containing alanine substitutions in these positions are incapable of inducing disease. The sequence "QKP" is present in MBP 113-142, and similarly, "PQK" is present in MBP 68-88. In PL/J mice, the $R$ and $P$ residues are critical

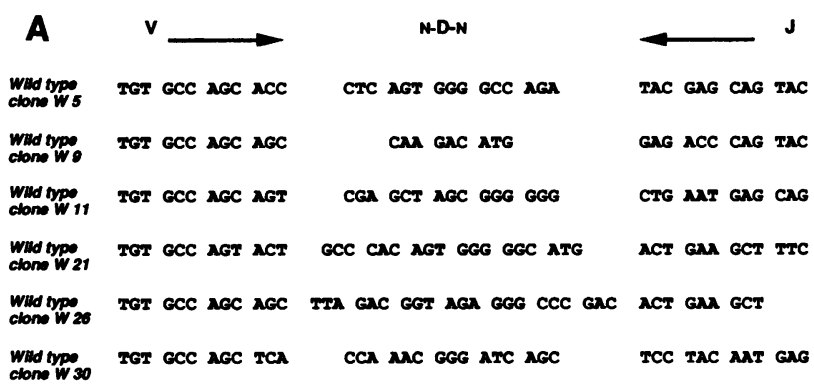

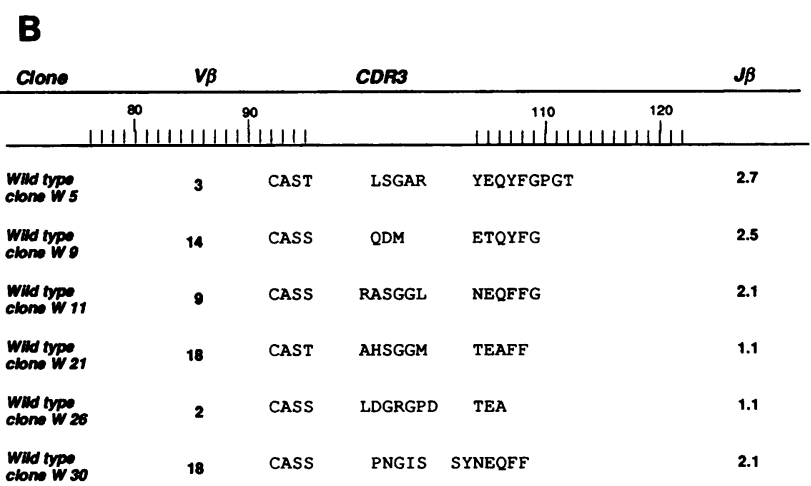

Figure 3. TCR $\beta$ chain usage and D-J region nucleotide $(A)$ and deduced amino acid sequences $(B)$ of five $h p r{ }^{+}$wild-type T cell clones from MS patient 3. Control clones were generated by PHA-activation concurrent with the hprt assay.

for binding to $\mathrm{A}_{\alpha}{ }^{ } \mathrm{A}_{\beta}{ }^{\mathrm{u}}$; the lysine is essential for disease induction and, in addition to the glutamine residue, is believed to interact with the TCR. The absence of the arginine in the epitope for these clones may simply reflect differential requirements for binding to the relevant human class II.

Since these clones were derived from patients with longstanding disease, they may indicate determinant spreading (31), with reactivity to secondary epitopes predominating the response to MBP in later stages of disease. This has been observed in EAE, and suggests that this class of activated T cells, as well as some of the clones described in the EAE system, and some TCRs from the brain and CSF either recognize relatively nondominant epitopes of MBP, or that the response to secondary epitopes plays an important role in disease maintenance. At the time of sampling, the patient from which the hprt ${ }^{-} \mathrm{T}$ cell clones were derived had MS for $6 \mathrm{yr}$.

Additional sequence data of $\mathrm{V} \beta 12$ TCRs from MS brain lesions $(16,17)$ will determine if these similarities in TCR expression can be extended to $\mathrm{T}$ cells found within the inflammatory lesion. The expression of TCR V genes and CDR3 sequences, both in the CSF and in T cell clones derived from the peripheral blood of MS patients, which are similar to those expressed by $T$ cells which are MBP-reactive and encephalitogenic in rodents, indicates that a $\mathrm{T}$ cell mediated immune response to MBP might be occurring in the central nervous system of MS patients. Given that the specificity of these T cells in rodents elicits EAE, such a response may also be pathogenic in humans with MS.

\section{Acknowledgments}

The authors wish to thank Ann Begovich and Henry Erlich for DR typing by PCR, and Ann Lodge for mapping epitopes for these clones. 
This work was supported by the National Institutes of Health. M. Allegretta was supported by the National Multiple Sclerosis Society.

\section{References}

1. McFarlin, D. E., and H. MacFarland. 1983. Multiple sclerosis. N. Engl. J. Med. 307:1183-1188.

2. Zamvil, S. S., P. A. Nelson, D. J. Mitchell, R. L. Knobler, R. B. Fritz, and L. Steinman. 1985. Encephalitogenic T cell clones specific for myelin basic protein. An unusual bias in antigen recognition. J. Exp. Med. 162:2107-2124.

3. Burns, F. R., X. Li, N. Shen, H. Offner, Y. K. Chou, A. Vandenbark, and E. Heber-Katz. 1989. Both rat and mouse $T$ cell receptors specific for the encephalitogenic determinants of myelin basic protein use similar $\mathrm{V} \alpha$ and $\mathrm{V} \beta$ chain genes. J. Exp. Med. 169:27-39.

4. Chluba, J., C. Steeg, A. Becker, H. Wekerle, and J. T. Epplen. 1989. T cell receptor beta chain usage in myelin basic protein-specific rat $\mathrm{T}$ lymphocytes. Eur. J. Immunol. 19:279-284.

5. Acha, O. H., D. J. Mitchell, L. Timmermann, D. C. Wraith, G. S. Tausch, M. K. Waldor, S. S. Zamvil, H. O. McDevitt, and L. Steinman. 1988. Limited heterogeneity of $\mathrm{T}$ cell receptors from lymphocytes mediating autoimmune encephalomyelitis allows specific immune intervention. Cell. 54:263-273.

6. Zaller, D. M., G. Osman, O. Kanagawa, and L. Hood. 1990. Prevention and treatment of murine experimental allergic encephalomyelitis with $\mathrm{T}$ cell receptor $\mathrm{V}$ beta-specific antibodies. J. Exp. Med. 171:1943-1955.

7. Wraith, D. C., D. E. Smilek, D. J. Mitchell, L. Steinman, and H. O. McDevitt. 1989. Antigen recognition in autoimmune encephalomyelitis and the potential for peptide-mediated immunotherapy. Cell. 59:247-255.

8. Steinman, L., J. T. Rosenbaum, S. Sriram, and H. O. McDevitt. 1981. In vivo effects of antibodies to immune response gene products: prevention of experimental allergic encephalitis. Proc. Natl. Acad. Sci. USA. 78:7111-7114.

9. Vandenbark, A. A., G. Hashim, and H. Offner. 1989. Immunization with a synthetic $\mathrm{T}$-cell receptor $\mathrm{V}$-region peptide protects against experimental autoimmune encephalomyelitis. Nature (Lond.). 341:541-544.

10. Howell, M. D., S. T. Winters, T. Olee, H. C. Powell, D. J. Carlo, and S. W. Brostoff. 1989. Vaccination against experimental allergic encephalomyelitis with T cell receptor peptides. Science (Wash. DC). 246:668-670.

11. Wucherpfennig, K., K. Ota, N. Endo, J. G. Seidman, A. Rosenzweig, H. L. Weiner, and D. A. Hafler. 1990. Shared human T cell receptor V $\beta$ usage to immunodominant regions of myelin basic protein. Science (Wash. DC). 248:1016-1019.

12. Kotzin, B., S. Karaturi, Y. Chou, J. Lafferty, J. M. Forrester, M. Better, G. E. Nedwin, H. Offner, and A. A. Vandenbark. 1991. Preferential T cell receptor $\mathrm{V}$ beta usage in myelin basic protein reactive to $\mathrm{T}$ cell clones from patients with multiple sclerosis. Proc. Natl. Acad. Sci. USA. 88:9161-9165.

13. Ben-Nun, A., R. Liblau, L. Cohen, D. Lehmann, E. Tournier-Lasserve, A. Rosenzweig, J. Z. J. Raus, and M. A. Bach. 1991. Restricted TCR V beta gene usage by myelin basic protein-specific $\mathrm{T}$ cell clones in multiple sclerosis: predominant genes vary in individuals. Proc. Natl. Acad. Sci. USA. 88:24662470

14. Martin, R., M. D. Howell, D. Jaraquemada, M. Flerlage, J. Richert, S. Brostoff, E. O. Long, D. E. McFarlin, and H. E. McFarland. 1991. A myelin basic protein peptide is recognized in the context of four HLA-DR types associated with multiple sclerosis. J. Exp. Med. 173:19-24.

15. Richert, J. R., E. D. Robinson, A. H. Johnson, C. A. Bergman, L. J. Dragovic, N. L. Reinsmoen, and C. K. Hurley. 1991. Heterogeneity of the T cell receptor beta gene rearrangements generated in myelin basic protein-specific $\mathbf{T}$ cell clones isolated from a patient with multiple sclerosis. Ann. Neurol. 29:299306.
16. Oksenberg, J. R., S. Stuart, A. B. Begovich, R. B. Bell, H. A. Erlich, L. Steinman, and C. C. Bernard. 1990. Limited heterogeneity of rearranged T-cell receptor $\mathrm{V}$ alpha transcripts in brains of multiple sclerosis patients. Nature (Lond.). 345:344-346.

17. Oksenberg, J. R., M. A. Panzara, A. B. Begovich, D. Mitchell, H. A. Erlich, R. S. Murray, R. Shimonkevitz, M. Sherrit, J. Rothbard, C. C. A. Bernard, and L. Steinman. 1993. Selection for T-cell receptor $\mathrm{V} \beta-\mathrm{D} \beta-\mathrm{J} \beta$ gene rearrangements with specificity for a myelin basic protein peptide in brain lesions of multiple sclerosis. Nature (Lond.). 362:68-70.

18. Lee, S. J., K. W. Wucherpfennig, S. A. Brod, D. Benjamin, H. L. Weiner, and D. A. Hafler. 1991. Common T-cell receptor V beta usage in oligoclonal T lymphocytes derived from cerebrospinal fluid and blood of patients with multiple sclerosis. Ann. Neurol. 29:33-40.

19. Birnbaum, G., and N. B. Van Ness. 1992. Quantitation of T-cell receptor $\mathrm{V}$ beta chain expression of lymphocytes from blood, brain, and spinal fluid in patients with multiple sclerosis and other neurological diseases. Ann. Neurol. 32:24-30.

20. Stout, J. T., and C. T. Caskey. 1985. HPRT: gene structure, expression, and mutation. Ann. Rev. Genet. 19:127-148.

21. Albertini, R. J., K. L. Castle, and W. R. Borcherding. 1982. T-cell cloning to detect the mutant 6-thioguanine-resistant lymphocytes present in human peripheral blood. Proc. Natl. Acad. Sci. USA. 79:6617-6621.

22. Morley, A. A., K. J. Trainor, R. Seshadri, and R. G. Ryall. 1983. Measurement of in vivo mutations in human lymphocytes. Nature (Lond.). 302:155-156.

23. Albertini, R. J., J. A. Nicklas, J. P. O'Neill, and S. H. Robison. 1990. In vivo somatic mutations in humans: measurement and analysis. Ann. Rev. Genet. 24:305-326.

24. Allegretta, M., J. A. Nicklas, S. Sriram, and R. J. Albertini. 1990. T cells responsive to myelin basic protein in patients with multiple sclerosis. Science (Wash. DC). 247:718-721.

25. Chothia, C., D. R. Boswell, and A. M. Lesk. 1988. The outline structure of the T-cell $\alpha \beta$ receptor. EMBO (Eur. Mol. Biol. Organ.) J. 7:3745.

26. Howell, M. D., J. P. Diveley, K. A. Lundeen, A. Esty, S. T. Winters, D. J. Carlo, and S. W. Brostoff. 1991. Limited T cell receptor beta chain heterogeneity among interleukin-2 receptor positive synovial $\mathrm{T}$ cells suggests a role for superantigen in rheumatoid arthritis. Proc. Natl. Acad. Sci. USA. 246:668-670.

27. Gold, D. P., M. Vainiene, B. Celnik, S. Wiley, C. Gibbs, G. Hashim, A. A. Vandenbark, and H. Offner. 1992. Characterization of the immune response to a secondary encephalitogenic epitope of basic protein in Lewis rats. II. Biased TCR V beta expression predominates in spinal cord infiltrating T cells. J. Immunol. 148:1712-1717.

28. Heber-Katz, E., and H. Acha-Orbea. 1989. The V-region disease hypothesis: Evidence from autoimmune encephalomyelitis. Immunol. Today. 10:164-169.

29. Paliard, X., S. West, J. Lafferty, J. Clements, J. W. Kappler, P. Marrack, and B. Kotzin. 1991. Evidence for the effects of a superantigen in rheumatoid arthritis. Science (Wash. DC). 253:325-329.

30. Gautam, A., C. Pearson, D. Smilek, L. Steinman, and H. O. McDevitt. 1992. A polyalanine peptide containing only five native basic protein residues induces autoimmune encephalomyelitis. J. Exp. Med. 176:605-609.

31. Lehmann, P. V., T. Forsthuber, A. Miller, and E. E. Sercarz. 1992. Spreading of $\mathrm{T}$-cell autoimmunity to cryptic determinants of an autoantigen. Nature (Lond.). 358:155.

32. Klein, M., P. Concannon, M. Everett, L. Kim, T. Hunkapiller, and L. Hood. 1987. Diversity and structure of human T cell receptor $\alpha$ chain variable region genes. Proc. Natl. Acad. Sci. USA. 84:6884-6888.

33. Kimura, N., B. Toyonaga, Y. Yoshikai, F. Triebel, P. Debre, M. Minden, and T. Mak. 1986. Sequences and diversity of human T cell receptor $\beta$ chain variable region genes. J. Exp. Med. 164:739-750.

34. Concannon, P., L. A. Pickering, P. Kung, and L. Hood. 1986. Diversity and structure of human $\mathrm{T}$ cell receptor $\beta$ chain variable region genes. Proc. Natl. Acad. Sci. USA. 83:6598-6602. 